\title{
Earthquakes in Italy: past, present and future
}

\author{
Istituto Nazionale di Geofisica e Vulcanologia - Via di Vigna Murata, 605 - Rome, Italy.valensise@ingv.it http://www.ingv.it/
}

\begin{abstract}
Italy has a long-standing tradition of earthquake investigations. Seismologists can rely on one of the longest and most detailed records of historical seismicity, 20 years of homogeneous and reliable instrumental data, systematic and widespread active stress data and a comprehensive database of potential seismogenic sources. Here we describe these datasets and discuss how they may help us anticipate the large earthquakes of the future.
\end{abstract}

\section{Introduction}

According to UNESCO, densely populated Italy hosts about $50 \%$ of the known cultural heritages of the entire globe. Italian cities are thus especially vulnerable to earthquakes that would not be as dangerous in other earthquake-prone countries. Damage to the frescoed vault of the San Francesco basilica in Assisi during the 1997 Umbria-Marche earthquake ( $\left.M_{w} 6.0\right)$ exemplifies Italy's special vulnerability.

Saving lives and protecting Italy's immense cultural patrimony are important responsibilities of Italian seismologists. But can the location and size of future large Italian earthquakes be anticipated with some confidence? Seismologists certainly know Sir Charles Lyell's famous motto "the present is the key to the past". They also know by everyday experience that the corollary to that statement, "the past is the key to the present", is just as true. But, most importantly for those concerned with the future of our planet, they are also learning that "the past and the present are the key to the future". The seismological translation of this motto is that "successful forecasting means projecting into the future what we learned from the past and witness in the present".

There are few countries where the earthquake record can be exploited at time scales from 10,000 years to seconds, but Italy is one of them. This record, properly organized into a knowledge continuum, allows several facets of the earthquake process to be investigated simultaneously. This paper describes how seismological information (instrumental and historical) and field evidence at different scales can be integrated to make realistic long-term earthquake forecasts in Italy. In the last section of this paper we propose a viable approach to this problem by introducing the concept of potential seismogenic source (Valensise and Pantosti, 2001a) a simplified three-dimensional scheme of a physical fault system.

\section{The past: Italy, the cradle of earthquake catalogues}

Italian seismicity today does not appear as frightful as it did a few centuries ago, at least in comparison with much larger earthquakes that take place in other parts of the globe. Nevertheless, Italian earthquakes have left a strong imprint on the country's landscape, heritage and traditions, and even place names and the distribution of dialects often reflect a large earthquake. Italians also learned early that to fight earthquakes you ought to know them: where they occur repeatedly, what damage they cause, what to expect after the main shock has struck. Major advancements in understanding earthquakes were spurred by catastrophic events that attracted the interest of contemporary scholars. Such is the case of the central-southern Italy earthquakes of 1456, which devastated a large portion of the peninsula between Abrutii and Basilicata. Giannozzo Manetti's De terraemotu libri tres, published in 1457, is the first known systematic study of Italian seismicity after Antiquity (see Guidoboni, 2000 for a review).

For over two centuries the cataloguing efforts continued, although the compilers often emphasised more the "portentous" nature of earthquakes rather than the associated risk. Marcello Bonito's Terra Tremante, written after the catastrophic 1688 Benevento earthquake (Campania, southern Italy), is the principal expression of seismology of that time and the herald of modern earthquake catalogues. Around the middle of the XVIII century, however, these efforts were somewhat frustrated by the popular theory of electricity that effectively detached earthquakes from geology and landscape to make them totally random.

The XIX century marked the onset of modern catalogues, which had by then become a real scientific tool. Earthquakes were again seen as a systematic and recurrent phenomenon stemming from "seismic centers", just as volcanic eruptions were known to take place always at the same spots. Modern catalogues thus became the basis for demonstrating the regularity of earthquakes, the main pillar of modern earthquake forecasts. Towards the end of the century, Italian seismologists Michele Stefano de Rossi and Giuseppe Mercalli devised the first systematic scales of earthquake intensity. By allowing objective assessment of earthquake effects at many localities, this step favored the transition from descriptive to modern parametric catalogues. It also allowed different events to be compared through their epicentral location and severity.

The great catalogue by Mario Baratta (1901), a compilation of nearly 1,400 Italian earthquakes between Antiquity and 1898, is the most mature outcome of these new trends. Perhaps due to the enormous advancement represented by this work and the concurrent rise of instrumental seismology, not much happened until 1935 when Alfonso Cavasino (1935) published an update of Baratta's catalogue. Ironically, his 35-year update had to account for four of the most dreadful earthquakes of Italian history: 1905, central Calabria; 1908, Messina Straits; 1915, Avezzano; 1930, Irpinia: all having M 7.0. Data collection became then systematic, leading to the first computerized catalogue in 1973. In the booming '70s and early ' $80 \mathrm{~s}$, also as a result of catastrophic earthquakes (1976, Friuli; 1980, Irpinia), research into historical seismicity had become a national priority. It is hence not surprising that a "consensus" catalogue published in 1985 contained almost 42,000 events (Postpischl, 1985).

The 1990s brought about yet another revolution in the task of retrieving, analyzing and storing historical earthquake data. In 1995, INGV released the first version of the Catalogue of Strong Earthquakes in Italy, a "new-generation" compilation that summarizes research conducted by ENEL (Italy's national electricity company) and the former ING (Istituto Nazionale di Geofisica) (Boschi et al., 2000). In addition to the standard source parameters, for each earthquake this catalogue supplied a set of specifically prepared summaries, details on the effects suffered in each locality involved, and a list of references. Two years later, this work was paralleled by the Internet-based compilation prepared within Italy's CNR (National Research Council) (Monachesi and Stucchi, 1997). Both compilations served as a basis for the Catalogo Parametrico dei Terremoti Italiani (CPTI Working Group, 1999), an updated version of the work completed by Postpischl in 1985. Individual datapoints allowed earthquake source parameters to be determined through an analytical technique which gave a statistical basis to 
subjective historical data (Gasperini et al., 1999). For the best documented earthquakes this technique also returns an estimate of source orientation and length, thus allowing the determination of a "virtual fault" for earthquakes that occurred centuries ago.

After investigating surface ruptures produced by the 1980 Irpinia earthquake $\left(M_{s} 6.9\right.$; e.g. Pantosti and Valensise, 1990), scientists started looking at historical earthquakes from the point of view of their impact on the environment (see Valensise and Guidoboni, 2000 for a review). Identifying major historical earthquake ruptures thus became a challenging but promising activity for many Quaternary geologists.

A further revolution in investigating Italy's past earthquakes is the onset of paleoseismological studies in the late '80s. Trenching of the fault responsible for the 1980 earthquake supplied evidence for at least four of its predecessors occurring every 2,000 yr on average (Pantosti et al., 1993). Subsequent trenching of a number of large faults confirmed these findings and returned fundamental constraints on the frequency of large Apennines earthquakes (see Valensise and Pantosti, 2001b for a review).

A recent attempt to extend the historical record back in time is the development of Archeoseismology, a discipline that explores evidence for destructive earthquakes emerging from the archeological record. For instance, a thorough reappraisal of the history of settlements and land-use in the Messina Straits during Antiquity supplied evidence for a large event of social and territorial disruption in the IV century (Guidoboni et al., 2000). This event was interpreted as a predecessor of the devastating 1908 earthquake, agreeing with geological estimates of 700-1,500 $\mathrm{yr}$ for the average repeat time of 1908-like events (Valensise and Pantosti, 1992). Additional promising work is progressing at different sites throughout the peninsula.

Combining paleoseismological and archeoseismological evidence suggests that (1) the typical repeat time for individual major Italian earthquake sources is 1,000-3,000 yr, and (2) apparently shorter recurrence intervals result from multiplicity of sources or stress triggering of events on adjacent sources. These findings are supported by missing "twins" of the very same earthquake throughout history. Although the infrequency of Italian quakes is clearly favorable, the mismatch between typical repeat times and the length of the reliable historical record ( $700 \mathrm{yr})$ implies that several important potential earthquake sources are not represented in current historical catalogues. One of them could go off in the next large earthquake, turning it into yet another "unexpected event".

Should we then suspect historical catalogues? Of course not. We will see later how this condition may be handled by carefully combining all available historical, geological, instrumental evidence. Meanwhile, Italian seismologists, planners, civil defense authorities and ordinary people are learning from the historical record. The earthquake distribution revealed by the CPTI (Figure 1) is surprising, because seismicity is widespread and moderate shocks seem to occur nearly everywhere; but unsurprising also, because most large earthquakes occur where they would be expected, given the current understanding of Italy's geodynamics.

\section{The present: understanding Italy's stress, strain and seismicity}

Present seismicity is the most direct evidence for ongoing tectonic activity. Unlike the causative faults of historical earthquakes, for which we normally recover only an approximate estimate of size and location, modern seismological instrumentation allows the most significant parameters to be assessed confidently. These include the hypocentral location and depth, source size, coseismic displacement, faulting mechanism and details of the rupture process.

In Italy, instrumental seismology started more than a century ago, and all large earthquakes of the XX century have been recorded by several seismic observatories. Recovering early historical seismograms and investigating these earthquakes have already proved

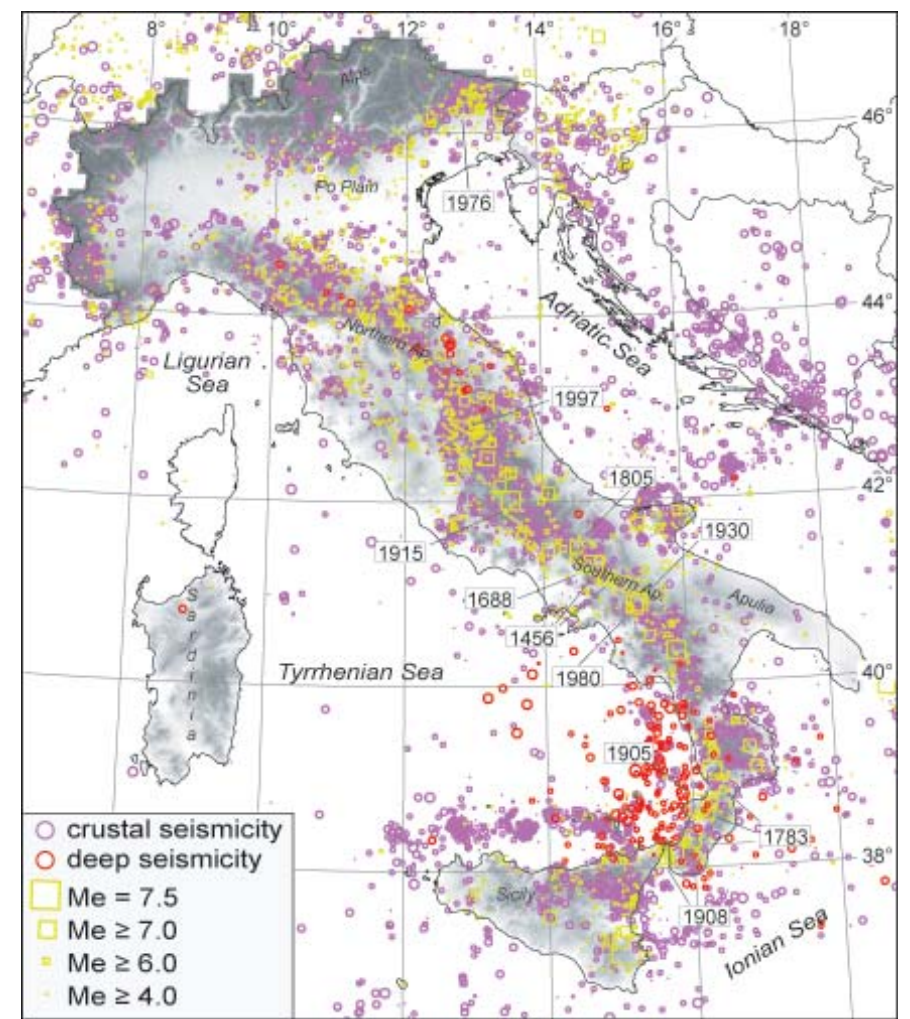

Figure 1 Historical seismicity from CPTI catalogue (CPTI Working Group, 1999) and instrumental seismicity from INGV bulletin (1983-2002, $M \geq 2.8$ ), both scaled by magnitude. Location of large earthquakes cited in text is also shown.

very promising (e.g., Pino et al., 2000) under SISMOS, a major project that started recently at INGV.

All magnitude $5.5^{+}$earthquakes of the past 30 years have been investigated by combining sparse data from "historical" Italian observatories and global networks that became operational in the early '70s (see Gasparini et al., 1985; Anderson and Jackson, 1987; INGV RCMT, 2003; among many others). Further details on seismic rupture, such as source duration, directivity and complexity, have also been retrieved thanks to the strong motion instruments formerly operated by ENEL and presently by Servizio Sismico Nazionale (SSN).

Systematic collection of short-period earthquake data began after the 1980 Irpinia earthquake, when the centralized Italian National Seismic Network began. Since then, the network has been steadily extended and improved in instrumentation and data reliability. Tens of thousands of earthquakes having magnitudes between $\sim 1.5$ (the detection threshold in the best instrumented parts of the country) and 6.0 ( $\mathrm{M}_{\mathrm{w}}$ of the 1997 Umbria-Marche event) were recorded. Several regional and local networks also contributed to highlight details of Italy's "earthquake structure". After twenty years of uninterrupted surveying, the Italian dataset of instrumental seismicity indeed represents a powerful tool for investigating the region's active tectonics (Figure 1). The resolution offered by this dataset, however, is insufficient to illuminate details of the seismic process in fault zones. Most information on Italian seismogenic faults at depth comes from dense, state-of-the-art portable networks temporarily deployed for aftershock studies. Important details on the geometry, kinematics and complexity of fault systems were identified with this tool. For example, detailed analyses of the 1997 Umbria-Marche sequence show that the fault zone changes within a very short distance from a simple linear, low-angle rupture plane to a complex flat-ramp geometry (Chiaraluce et al., 2003). Overall, the data highlighted the role of shallow structural complexities, both parallel and perpendicular to the main fault, in determining rupture behavior (Chiarabba and Amato, 2003).

Besides aftershock studies, advancements in the understanding of active tectonics and fault zones were spurred by field experiments 
based on modern seismological arrays and large mass storage capabilities. The first experiment (2001-2002) was a six-month campaign that shed light on the geometry and kinematics of major active fault systems in northern Umbria (central Apennines). The results confirmed that these experiments are extremely promising, provided that the array is well designed and the earthquake rate is significant in comparison with the detection threshold (the largest recorded quake was only 3.0).

A recent but valuable source of information on Italy's active tectonics is the systematic analysis of in-situ stress data, essentially borehole breakouts in deep wells. It is now widely accepted that computing their average azimuthal distribution yields the local orientation of the horizontal stress field (Bell and Gough, 1983; Zoback et al., 1985). In the early nineties INGV started systematic activity in this field by cooperating with ENI-AGIP and other oil and geothermal companies in Italy. Over 300 wells have been analyzed so far (Montone et al., 1999). Along with earthquake fault plane solutions and fault slip data, breakout analyses yielded an image of present-day stress orientation in Italy (Figure 2) which now contains over 500 minimum horizontal stress directions $\left(S_{\mathrm{hmin}}\right)$ (Montone et al., 2003, and references therein). Stress directions obtained from different data have been found mutually consistent, despite the fact that they often refer to different depth intervals $(0-7$ $\mathrm{km}$ for breakouts, $0-20 \mathrm{~km}$ for crustal earthquakes) and different tectonic units. The inferred pattern confirms that the stress field in Italy's brittle crust is due to the interaction of "large scale" processes with "local sources". Stress data can be used to understand active tectonic processes, assess seismic hazard, and anticipate the behavior of seismogenic faults. Such data also represent a benchmark for geodynamic modeling of the central Mediterranean.

Information on the present strain field is commonly obtained from geodetic observations spanning at least a decade of ongoing tectonic activity. Unfortunately, Italy's strain field is still poorly known due to (1) the lack of a homogeneous and dense GPS network, and (2) the low ratio between strain rates and accuracy of the measurements. Nevertheless, first order estimates have already been

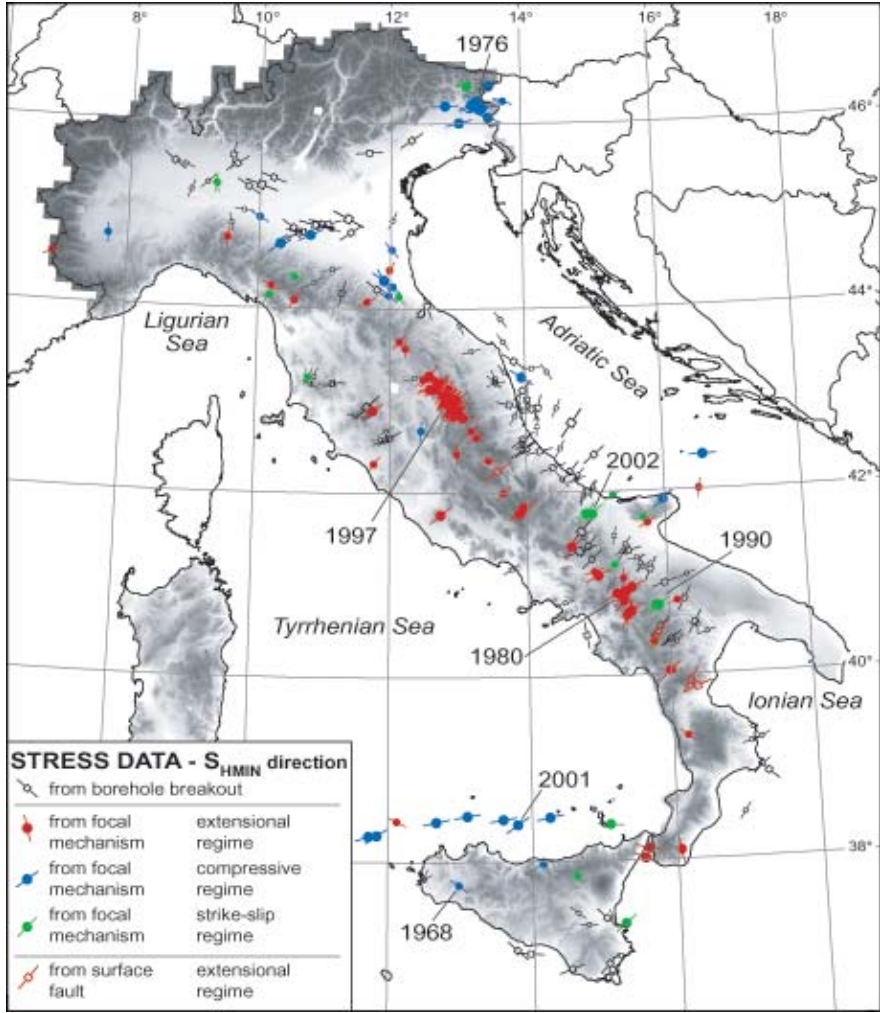

Figure 2 Active stress map of Italy with minimum horizontal stress orientations (from Montone et al., 1999, slightly modified and updated), and location of selected significant recent earthquakes. obtained based on IGM95 (a network established and maintained by Istituto Geografico Militare) (D'Agostino et al., 2001), periodic resurveys of regional networks (Anzidei et al., 2001; Calais et al., 2002), and GPS resurveying of the national triangulation network set up by IGM in 1869-1881 (Hunstad et al., 2003). Owing to the exceptionally long time-span in comparison with the estimated uncertainties, this latter technique recently revealed that (a) peninsular Italy extends at $2.5-5.0 \mathrm{~mm} / \mathrm{y}$, (b) deformation is concentrated in a region a few tens of $\mathrm{km}$ wide straddling the crest of the Apennines, and (c) $70-80 \%$ of this strain has not been released by earthquakes and must occur aseismically.

By comparing recent and historical seismicity, the stress and strain fields gathered from all available data and the deep structure recovered from seismic tomography, seismologists were able to set firm constraints on Italy's active tectonics (refer to Figures 1, 2 together):

- most of Italy is seismically active, except for a few stable areas such as Sardinia, southern Apulia and limited parts of northern Italy and Sicily;

- this almost continuous seismic belt follows the buried margin of the Adriatic microplate beneath the Apennines and the Alps; the boundary between the Ionian lithosphere and the Calabrian arc; the boundary between the "African" foreland and the Sicilian nappes in Sicily;

- earthquakes are sparse along the Alpine arc, from the Ligurian Sea to Friuli, with a lesser density in the central Alps. Alpine earthquakes directly testify to the $\sim \mathrm{N}-\mathrm{S}$ push of the Adriatic microplate, as shown by the thrust faulting mechanism of the 1976 Friuli events;

- widespread seismicity characterizes the northern Apennines arc, from northern Tuscany to Latium. Spots of low-magnitude seismicity punctuate Quaternary volcanoes and geothermal fields in the inner portion of the arc. The actively deforming belt extends from the inner Apennines basins, where seismicity results from crustal extension perpendicular to the belt ( $\mathrm{S}_{\mathrm{hmin}}$ oriented NESW), to the most external arcs buried beneath the Po Plain and the Adriatic offshore, where earthquakes reveal ongoing convergence ( $\mathrm{S}_{\mathrm{hmin}}$ oriented NW-SE). Although the mechanism driving this arc evolution is still debated, the presence of earthquakes down to $90 \mathrm{~km}$ depth (Selvaggi and Amato, 1992) and a strong high-velocity anomaly in the upper mantle beneath the northern Apennines (e.g. Lucente et al., 1999) support an actively retreating slab. This view is challenged by investigators who explain the same evidence in a context of prevailingly passive intra-continental rift (e.g., Lavecchia et al., 2003). In the northern Apennines, seismological evidence for extension and compression consistently agrees with the Neogene evolution of the region, although some investigators contend that compression died out before the end of Middle Pleistocene (Di Bucci and Mazzoli, 2002).

- a relatively narrow belt of seismicity characterizes the southern Apennines, where earthquakes are larger $(\mathrm{M} \sim 7)$ than in the northern arc and individual faults are up to 30-50 km long. Earthquake and active stress data consistently reflect dominant ongoing NE$\mathrm{SW}$ extension. Conversely, the role of E-W right-lateral strikeslip faults revealed by recent moderate-size earthquakes (e.g. Potenza, 1990; Molise, 2002) and affecting the Apulian foreland is still unclear. Such quakes may result from lateral complexities, accommodate different rates of extension, or represent the reactivation of pre-existing major faults dating back to the construction of the Apennines edifice;

- contrary to what is revealed by seismic tomography in the northern Apennines, the deep structure of the southern Apennines is dominated by a detached (or possibly less dense) lithospheric slab, which could be the engine of uplift and extension of the orogen;

- a narrow Wadati-Benioff zone is beautifully imaged in the Calabrian arc. Shallow earthquakes are recorded inland, whereas intermediate and deep events are recorded beneath the southern Tyrrhenian. The subduction zone is only $200 \mathrm{~km}$ wide but extends much more down-dip, reaching and possibly penetrating the $660 \mathrm{~km}$ discontinuity (Lucente et al., 1999; Amato and Cimini, 2001; Piromallo and Morelli, 2003). Intriguing features of this deep activity are the geometry of the Ionian slab, which 
appears to sink passively in the mantle, and the slab's interior earthquake mechanism, a consistently down-dip compression;

- seismicity of Sicily results from processes interacting at very short distance and giving rise to an especially complex setting: roughly E-W extension in the Messina Straits, consistent with what is seen in the adjacent Calabrian arc; dense spots of largely extensional earthquakes around Mt. Etna; strike-slip earthquakes along eastern Sicily at the boundary between the Ionian lithosphere and the Sicilian foreland; a transverse structure bounding the Calabrian subduction to the west (Tindari-Letoianni lineament auct.); N-S compressional earthquakes in northern (2001 Palermo, $\mathrm{M}_{\mathrm{W}}$ 5.4) and central-western Sicily (1968 Belice, $M_{\mathrm{W}}$ 5.6).

\section{The future: long-term earthquake forecast Italian-style}

In 1999, the Italian Dipartimento per la Protezione Civile (Civil Defense) launched a plan for seismic retrofitting of the country's historical centers and sought help from the scientific community to establish intervention priorities. This was not a standard or easy scientific problem for Italy, where seismic hazard is traditionally assessed based on the statistical distribution of historical and instrumental earthquakes with subordinate geologic and tectonic constraints (e.g. Albarello et al., 1999). This approach rather accurately determines rates of non-destructive earthquakes, constrains the maximum credible magnitude over extended regions $(\sim 100 \mathrm{~km})$ and supplies reasonable probabilistic estimates of the expected ground shaking. However, little information on the physical properties of major seismogenic sources can be directly deduced from historical catalogues, and the contribution of instrumental data is clearly limited to earthquakes that occurred after the inception of modern seismological networks. Identifying large active faults geologically is normally a viable alternative, but Italy's complex tectonic history makes this approach quite problematical. In summary, none of these basic contributions (historical and instrumental seismicity, geodesy, geologic and tectonic data) may be used alone either to anticipate the location and size of future large earthquakes or to assess the characteristics of the associated ground shaking.

In 2000, a team of INGV scientists gathered to submit a large research project within the 2001-2003 Framework Program of GNDT (Gruppo Nazionale per la Difesa dai Terremoti, funded by the Italian Civile Defense: http://gndt.ingv.it/). The project, entitled "Probable earthquakes in Italy 2000-2030: guidelines for determining priorities in seismic risk mitigation", was intended as a direct response to the government request for identifying priority areas for seismic risk mitigation. This project was to blend several recent developments in Italian seismology and earthquake geology. These include fault identification and characterization with different tools; evaluation of seismic and geodetic strain to constrain hazard estimates; studies of regional seismic wave propagation and attenuation; studies of local site response; and development of time-dependent hazard evaluation tools incorporating innovative information on fault behavior and earthquake recurrence.

The starting point of the project's strategy is a fault segmentation model of Italy that was developed by INGV scientists starting in 1996. The model rests on the assumption that seismicity may be approximated by a finite number of potential seismogenic sources. It was based on available good historical data (see $\$ 2$ ), important findings arising from instrumental seismicity (see $\S 3$ ) and the awareness of the specificity of active faulting in Italy, and was eventually structured as a GIS-supported database ("Database of Potential Sources for Earthquakes Larger than Magnitude 5.5 in Italy": Valensise and Pantosti, 2001a).

A potential seismogenic source is the surface projection of an inferred fault which is likely to experience a significant earthquake in the future. Not all potential sources will have earthquakes, and not all earthquakes will necessarily occur on identified potential sources, but in general the list of seismic sources should serve well as a basis for hazard estimation. Some potential sources have been identified from faulting or shaking in past earthquakes, while others have been inferred from more indirect observations. Each source is assumed to represent a discrete segment of a longer seismogenic zone. In its turn, each segment is assumed to generate its largest allowed or "characteristic" earthquake, not necessarily periodic. Although seemingly crude, these assumptions are being proved realistic in regions dominated by dip-slip faulting away from the main active plate boundaries, such as Italy.

The current release of the segmentation model (Figure 3) lists about 250 potential earthquake sources grouped according to their identification criteria and parameter assessment. New sources were added or improved during the GNDT project, particularly in poorly documented and strategic areas of the country. Most sources align along well-established tectonic trends coincident with those identified by instrumental and historical seismicity (see $\S 2,3$ ). Overall the Italian peninsula can be seen as a segmented belt of discrete seismogenic faults, at least to a first approximation. The best-identified segments are often neatly juxtaposed; their boundaries often coincide with "transverse lineaments" inherited from past tectonic phases and currently imprinted in the highly heterogeneous Italian crust.

Careful inspection of Italy's seismogenic sources reveals that some segments or longer sections of the seismogenic belt are not associated with known historical events. Can they be simply regarded as "seismic gaps"? Should we assume these areas have been accumulating stress for several centuries or millennia, and therefore are much more likely to rupture in the near future than any other Italian seismogenic area? Probably, but we must be very cautious. These faults certainly accommodate part of the deformation accumulated by ongoing tectonic activity. In the long-term $\left(10^{4}-10^{5}\right.$ y) the process of recharge and sudden release of tectonic stress is relatively periodic, but in the short-term $\left(10^{2}-10^{3} \mathrm{y}\right)$ it is certainly modulated by such effects as stress transfer after large earthquakes (e.g.

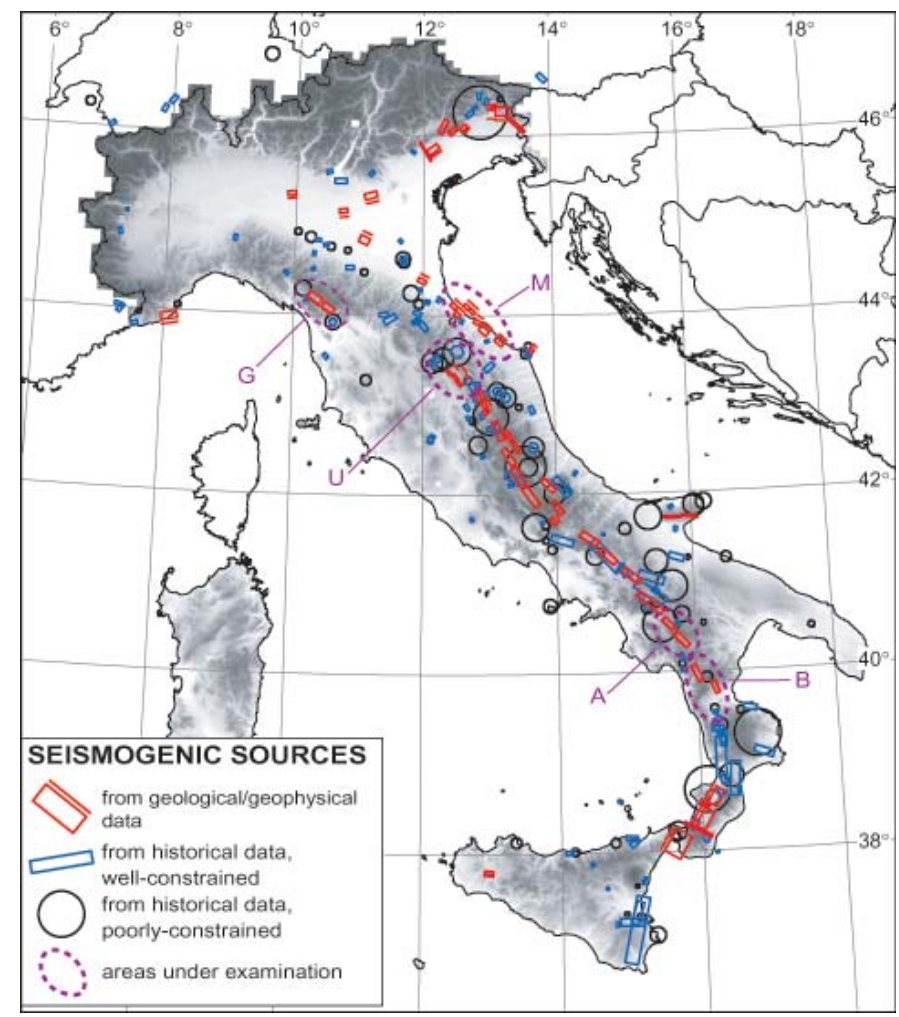

Figure 3 Segmentation model of Italy, showing main trends of identified seismogenic sources (derived from Valensise and Pantosti, 2001a). Areas outlined by a dashed line contain at least one silent seismogenic source and are the object of investigation by the GNDT project "Probable earthquakes in Italy 2000-2030" (from north to south: Garfagnana, northern Tuscany; northern Marche coastal belt; northern Umbria; Agri-Melandro, southern Apennines; Basilicata-Calabria border). See project's reports and Valensise and Pantosti (2001a) for further details. 
King and Cocco, 2000), lateral heterogeneities inducing creeping behavior of sections of the belt, or others yet to be explored.

Some potential gap areas (highlighted in Figure 3 and listed in caption) are currently being investigated by several of the GNDT project participants. Understanding the nature and role of structural complexities, the rate of tectonic stress accumulation vs. stress release in individual earthquakes, the ratio of seismic vs. non-seismic strain, the variations of stress and faulting style with depth are some of the challenges faced by Italy's modern seismology and earthquake geology. Nevertheless, positive identification and characterization of these the potential gaps and the hypothesized structural control have obvious implications for seismic hazard. Several forecasts concerning the locus of rupture initiation/termination and the approximate size of forthcoming large earthquakes will be issued at the end of the project. Success of even one would prove that modern seismology is ready to win against the apparently random nature of earthquakes, and that Sir Charles Lyell was right once again.

\section{References}

Albarello, D., and 8 others, 1999, New seismic hazard maps of the Italian territory: available at http://www.serviziosismico.it/PROG/2000/ carte_pericolosita/.

Amato, A., and Cimini, G.B., 2001, Deep structures from seismic tomography, in Vai, G.B., and Martini, I.P., eds, Anatomy of an Orogen: the Apennines and Adjacent Mediterranean Basins: Kluwer Academic Publisher, pp. 33-46.

Anderson, H., and Jackson, J., 1987, Active tectonics of the Adriatic region: Geophysical Journal Royal Astronomical Society, v. 91, pp. 937-987.

Anzidei, M. and 7 others, 2001, Insights into present-day crustal motion in the central Mediterranean area from GPS surveys: Geophysical Journal International, v. 146 , pp. $98-110$.

Baratta, M., 1901, I terremoti d'Italia. Saggio di storia geografia e bibliografia sismica italiana, Torino 1901, pp. 951.

Bell, J.S., and Gough, D.I., 1983, The use of borehole breakouts in the study of crustal stress, in Zoback, M.D., and Haimson, B.C., eds, Hydraulic Fracturing Stress Measurements, Natl. Acad. Press, Washington, D.C., pp. 201-209.

Boschi, E., Guidoboni, E., Ferrari, G., Mariotti, D., Valensise, G., and Gasperini, P., 2000, Catalogue of Strong Italian Earthquakes from 461 B. C. to 1997: Annali di Geofisica, v. 43, no. 4, pp. 607-868, with Database on CD-ROM.

Calais, E., Nocquet, J.M., Jouanne, F., and Tardy, M., 2002, Current strain regime in the Western Alps from continuous Global Positioning System measurements, 1996-2001: Geological Society of America Bulletin, v. 30(7), pp. 651-654.

Cavasino, A., 1935, I terremoti d'Italia nel trentacinquennio 1899-1933: Memorie del R. Ufficio Centrale di Meteorologia e Geofisica, s. III, 4, pp. 266.

Chiarabba, C., and Amato, A., 2003, Vp and Vp/Vs images in the Mw 6.0 Colfiorito fault region (central Italy): a contribute to understand seismotectonic and seismogenic processes, J. Geophys. Res., v. 108, in press.

Chiaraluce, L., Ellsworth W.L., Chiarabba, C. and Cocco, M., 2003, Imaging the complexity of an active normal fault system: the 1997 Umbria-Marche (central Italy) case study: J. Geophys. Res, v. 108, in press.

CPTI Working Group, 1999, Catalogo parametrico dei terremoti italiani: GNDTING-SGA-SSN (publ), Bologna July 1999, pp. 88, also available at http://emidius.mi.ingv.it/CPTI.

D’Agostino, N., Giuliani, R., Mattone, M. and Bonci, L., 2001, Active crustal extension in the central Apennines (Italy) inferred from GPS measurements in the interval 1994 and 1999: Geophysical Research Letters, v. 28(10), pp. 2121-2124.

Di Bucci, D., and Mazzoli, S., 2002, Active tectonics of the Northern Apennines and Adria geodynamics: new data and a discussion: Journal of Geodynamics, v. 34, pp. 687-707.

Gasparini, C., Iannaccone, G. and Scarpa, R., 1985, Fault-plane solutions and seismicity of the Italian peninsula: Tectonophysics, v. 117, pp. 59-78.

Gasperini, P., Bernardini, F. ,Valensise, G. and Boschi, E., 1999, Defining seismogenic sources from historical earthquake felt reports: Bulletin of Seismological Society of America, v. 89, pp. 94-110.

Guidoboni, E., 2000, Method of investigation, typology and taxonomy of the basic data: navigating between seismic effects and historical contexts: Annali di Geofisica, v. 43, no. 4, pp. 621-666.

Guidoboni, E., Muggia, A., and Valensise, G., 2000, Aims and methods in Territorial Archaeology: possible clues to a strong IV century A.D. earthquake in the Straits of Messina (southern Italy): in McGuire et al. (eds), The Archaeology of Geological Catastrophes, Geological Society, London, Special Publications, v. 171, pp. 45-70.

Hunstad, I., Selvaggi, G., D’Agostino, N., England, P., Clarke, P and Pierozzi, M., 2003, Geodetic strain in peninsular Italy between 1875 and 2001: Geophysical Research Letters, v. 30, n. 4, 1181, doi: 10.1029/2002GL016447.
King, G.C.P., and Cocco, M. 2000, Fault interaction by elastic stress changes: new clues from earthquake sequences: Advances in Geophysics, v. 44, pp.1-38.

INGV RCMT, 2003, Catalogue of European-Mediterranean Regional Centroid Moment Tensors, available from http://www.ingv.it/seismoglo/ RCMT/.

Lavecchia, G., Boncio, P., Creati N., and Brozzetti F., 2003, Some aspects of the Italian geology not fitting with a subduction scenario: Journal of the Virtual Explorer, submitted.

Lucente, F.P., Chiarabba, C., Cimini, G.B., and Giardini, D., 1999, Tomographic constraints on the geodynamic evolution of the Italian Region: Journal of Geophysical Research, v. 104, pp. 20307-20327.

Montone, P., Amato, A., and Pondrelli, S., 1999, Active stress map of Italy: Journal of Geophysical Research, v. 104, pp. 25595-25610.

Montone, P., Mariucci, M.T., Pondrelli, S., and Amato, A., 2003, An improved stress map for Italy and surrounding regions (Central Mediterranean): Earth and Planetary Science Letters, submitted.

Monachesi, G., and Stucchi, M., 1997, DOM4.1, un database di osservazioni macrosismiche di terremoti di area italiana al di sopra della soglia del danno: GNDT Internal Report, (available at http://emidius.mi.ingv.it/ DOM).

Pantosti, D., and Valensise G., 1990, Faulting mechanism and complexity of the 23 November 1980 , Campania-Lucania earthquake, inferred from surface observations: Journal of Geophysical Research, v. 95, pp. 15319-15341.

Pantosti, D., Schwartz, D. P., and Valensise, G., 1993, Paleoseismology along the 1980 surface rupture of the Irpinia fault: implications for earthquake recurrence in the southern Apennines, Italy: Journal of Geophysical Research, v. 98 , pp. 6561-6577.

Pino, N.A., Giardini, D. and Boschi, E., 2000, The December 28, 1908, Messina Straits, southern Italy, earthquake: waveform modeling of regional seismograms: Journal of Geophysical Research, v. 105, pp. 25473-25492.

Piromallo, C., and Morelli, A., 2003, P-wave tomography of the mantle under the Alpine-Mediterranean area: Journal of Geophysical Research, v. 108, B2, 2065, 10.1029/2002JB001757.

Postpischl, D., 1985, Catalogo dei terremoti italiani dall'anno 1000 al 1980 , Quaderni della Ricerca Scientifica, 114, 2B, Bologna 1985, pp. 239.

Selvaggi, G., and Amato, A., 1992, Subcrustal earthquakes in the northern Apennines (Italy): Evidence for a still active subduction?: Geophysical Research Letters, v. 19, pp. 2127-2130.

Valensise, G., and Guidoboni, E., 2000, Earthquake effects on the environment: from historical descriptions to thematic cartography: Annali di Geofisica, v. 43, pp. 747-763.

Valensise, G., and Pantosti, D., 1992, A 125 Kyr-long geological record of seismic source repeatability: the Messina Straits (southern Italy) and the 1908 earthquake (MS 71/2): Terra Nova, v. 4, pp. 472-483.

Valensise, G., and Pantosti, D., 2001a, The investigation of potential earthquake sources in peninsular Italy: a review: Journal of Seismology, v. 5, pp. 287-306.

Valensise, G., and Pantosti, D. (eds), 2001b, Database of Potential Sources for Earthquakes Larger than M 5.5 in Italy: Annali di Geofisica, v. 44(4) Suppl., pp 797-964, with CD-ROM.

Zoback, M. D., Moos, D., Mastin, L., and. Anderson, R.N, 1985, Well bore breakouts and in situ stress: Journal Geophysical Research, v. 90, pp. 5523-5530.

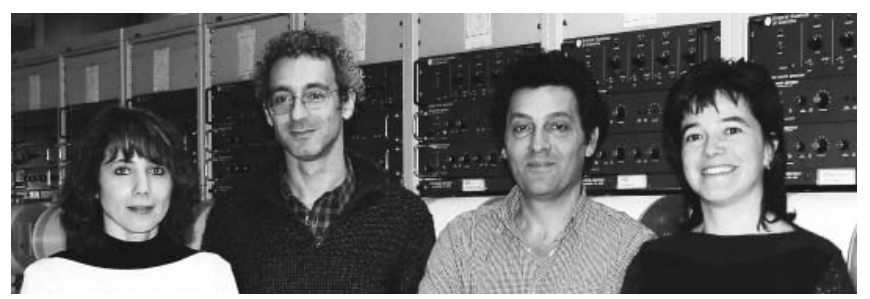

P.M., A.A., G.V., and D.P. (from left) graduated in Earth Sciences at Rome University "La Sapienza" between 1982 and 1986. G.V. and A.A. have been with Istituto Nazionale di Geofisica since 1983. P.M and D.P. joined it in 1992 and 1987, respectively. They share a great interest in the active tectonics and seismogenic processes of the Italian region, and have given special emphasis to the geometrical and mechanical characterization of seismogenic sources in their respective fields of expertise. G.V. and D.P. focused specifically on historical and prehistorical seismicity, on the quantification of the main earthquake sequences of the XX century and on developing tools for investigating hidden and blind faults. A.A. and P.M. concentrated on Italy's present stress field from earthquake and borehole data, on intermediate and deep earthquakes of the Italian subduction-collision zones and on the structure of the lithosphere beneath the peninsula. 